\title{
Probiotics Potential of Yeast and Lactic Acid Bacteria Fermented Foods and the Impact of Processing: A Review of Indigenous and Continental Food Products
}

\author{
Mabel Kyei Kwofie1 (1), Nafisatu Bukari1, Oluwaseyi Adeboye² \\ ${ }^{1}$ Department of Human Nutrition, McGill University, Ste Anne-de-Bellevue, QC, Canada \\ ${ }^{2}$ Department of Animal Science, McGill University, Ste Anne-de-Bellevue, QC, Canada \\ Email: mayekwofie@gmail.com
}

How to cite this paper: Kwofie, M.K. Bukari, N. and Adeboye, O. (2020) Probiotics Potential of Yeast and Lactic Acid Bacteria Fermented Foods and the Impact of Processing: A Review of Indigenous and Continental Food Products. Advances in Microbiology, 10, 492-507.

https://doi.org/10.4236/aim.2020.109037

Received: August 24, 2020

Accepted: September 26, 2020

Published: September 29, 2020

Copyright $\odot 2020$ by author(s) and Scientific Research Publishing Inc. This work is licensed under the Creative Commons Attribution International License (CC BY 4.0).

http://creativecommons.org/licenses/by/4.0/ (c) (i) Open Access

\begin{abstract}
Probiotics have become essential in food safety and health discourse with interest in their availability, stability, nutrition, and health implications. In this paper, an overview of probiotics of yeast and lactic acid, bacterial fermented food is presented. Probiotics of Lactobacillus spp. and Bifidobacterium spp.'s activities and processes within the human intestinal system are examined. Yeast and lactic acid bacterial (LAB) fermented foods from classified food groups such as vegetables, cereals, and grains, soybean, milk, fish, meat, and beverages are examined. This paper focuses on probiotic (microorganism) strains identified with food and their potential health and nutrition benefits. Finally, the impact of processing parameters and non-process factors on probiotics potential in fermented food is investigated.
\end{abstract}

\section{Keywords}

Probiotics, Lactobacillus spp, Bifidobacterium spp, Yeast, Lactic Acid Bacterial (LAB), Fermentation, Food Products

\section{Introduction}

The human gut microflora is made up of many species of bacteria. The different bacteria host in the intestinal tract functions in varying ways; while some segment of the gut bacteria renders beneficial health roles in the gut microflora, some bacteria are potentially harmful to the gut and hence to the body. Probiotics, a "live microorganism" [1] has been found to hinder the activities of the toxic bacteria, thereby promoting good health and preventing diseases [2] when 
introduced into the body. Lactic acid bacteria (LAB) and Yeast fermented Indigenous and continental food products are considered to have "probiotics" properties due to claims of their beneficial roles in the gut microbiome of consumers, they create a healthy gut environment for the human host. However, [3] have emphasized that a probiotic product must contain a "live microorganism" in compliance with its scientific definition. In this review, we are researching the "probiotic potential" of yeast and lactic acid bacteria (LAB) fermented foods of indigenous and continental food products. The objective of the study is to: 1) determine the probiotics microbe associated with yeast and lactic acid fermented food products; 2) identify the microbial activity of yeast and lactic acid bacteria (LAB) in fermented foods products; and 3) evaluate the impact of processing parameters and non-process factors on probiotics potential of fermented foods.

\section{Overview of Probiotics}

Probiotic is a Greek word meaning "For life" in contrast to antibiotics, which means "against life". Probiotics linkage with the intake of fermented foods was noticed during the ancient Greek and Roman era [3] [4]. The term "probiotic" defines substances that stimulate the growth of other microbes; this description was first used in 1965 by Lilly and Stillwell.

In 1907, Elie Metchnikoff, a Nobel Prize winner, first suggested that probiotic microbes have beneficial effects in the health of humans. He hypothesized that fermented milk products, which consisted of rod-shaped bacteria (Lactobacillus spp.), rendered people (Bulgarians) healthy. They lived longer since the bacteria affected the gut microflora positively and decreased the toxic microbial activity of its consumers [5].

In 1974, Parker first used the term "probiotic" as being currently used. Parker described "probiotic" as substances and organisms that contribute to intestinal microbial balance. However, Fuller modified the term in 1989. He defined probiotic as a live microbial supplement that affects the host's health positively by enhancing its intestinal microbial balance [6]. Hill, Guarner [1] asserted "Probiotics" must contain a "live micro-organism" that can confer a health benefit on the host when the appropriate amount is administered [1].

FAO/WHO defined probiotics as "live microbes" that, when ingested in the right quantity, provide beneficial health function for the host [7]. Accordingly, they indicated that probiotics status is valid when a substance meets requirements such as Strain identity, genus, strain level, and species assessable. They also stated that in vitro screening tests of possible probiotics is required, (gastric acidity resistance, digestive enzymes, and bile acids, antimicrobial action against possibly pathogenic bacteria must be confirmed). Also, in vivo research must be conducted on the target host for validation of the health impact. Safety should also be evaluated. [7].

\subsection{Probiotics Strains}

The probiotic microorganisms generally belong to the species Bifidobacterium, Streptococcus (thermophilus), Enterococcus, and Lactobacillus. [8] 


\subsection{Process of Probiotics Actions}

Probiotic microbes support the health of the human host. The mechanism of probiotics action as explained by [9] [10] [11] [12] [13] includes Adhesion sites blockage, production of inhibitory substances, stimulating immunity, competing for nutrients and degrading the toxin receptor. Probiotics inhibit pathogens through attaching to the intestinal epithelial surfaces, hence, blocking the adhesion sites. The production of substances such as organic acids, hydrogen peroxide, and bacteriocins are inhibitory to gram-positive and gram-negative bacteria. The stimulation of immunity ensures the host is protected from intestinal disease. Probiotics inhibit pathogens by ingesting the nutrients that pathogens need to survive. Finally, it degrades the toxin receptor. For instance, it has been revealed that $S$. boulardii defends the host from $C$. difficile intestinal disease. Some other mechanisms of probiotics actions are: the inhibition of contaminant production, the decrease of gut $\mathrm{pH}$, mitigation (reduce) of virus probiotics and gastrointestinal microflora balance [9] [10] [11] [12] [13].

Greater than 400 microbial species reside in the human gut microbiota. The human intestinal ecosystem is a complex one with both facultative anaerobic and obligate anaerobic microbes. Generally, the number of species is steady since they independently have their growth. The human gut microbiota composition, although constant, is often affected by diet, age, environment, medication, and stress. A healthy intestinal environment requires the maintenance of balanced bacteria, however, altering lifestyles of people have made this difficult to achieve. Multiple factors could change the friendly and beneficial intestinal bacteria to possibly hostile or pathogenic microbes, rendering the human host highly susceptible to sickness. In such case, the dominance of useful microbes must be supported. "Probiotics" use enables the protection of the human host from different intestinal illnesses and conditions by increasing the number of helpful bacteria and creating a steady balance once more [9] [10] [12] [13]. Probiotics are thought of as food that brings balance to the human intestinal flora. It has been used in many years for human and animal consumption with no side effects [7].

Probiotics are naturally available in the mouth, lower intestine, and other parts of healthy individuals; it supports the human body to defend itself against colonizing pathogenic microbes. However, the dominance of regular antibiotic medication has rendered the loss of much healthy intestinal flora.

In a healthy person, there is a stable balance between harmful and beneficial microorganisms in their intestinal environment (flora). Amongst the beneficial (good) bacteria are Lactobacillus spp. and Bifidobacterium spp., they play a significant role in the making of vitamins, organic acids, and antimicrobial factors that impede pathogens. Any imbalance in the gut microbiota leads to domination by harmful bacteria in the intestinal environment, which affects the making of essential nutrients, and intensifies the level of damaging materials, including carcinogens, putrefactive products and contaminants [14]. Fermented foods are developed out of microbial activities. They often contain probiotic strains. 


\section{Overview of Food Fermentation}

Fermentation is an ancient technology used for the making of food products of desirable properties such as useful organoleptic properties and prolonged shelf-life, which has improved microbial stability and safety that can be kept at ambient temperature [15]. Fermentation is a component of food safety beyond food preservation; the association of food fermentation and human health was discovered in ancient Rome and China [16].

The science of fermentation is termed Zymology, and the word fermentation was derived from the Latin word Fevere, which was defined by Pasteur Louis 1857 ) as "La vie sans l'air" which means "life without air". He connected yeast to fermentation.

Fermentation is a means of producing ATP through the degradation of natural nutrients anaerobically in the presence of appropriate microorganisms [17]. The fermentation process converts pure sugar into gases, organic acids, carbon dioxide, and alcohol in the absence of oxygen. It provides beneficial roles, such as in desirable food tastes and texture, and most importantly, offers probiotic bacterial properties (Lactobacillus spp., Streptococcus spp. etc.) and hinders pathogens from the food [18].

The key fermentation roles are 1) Inhibitory metabolites formation for food preservation such as organic acid (formic acid, lactic acid, propionic, and acetic acid, ethanol, $\mathrm{CO}_{2}$-carbon dioxide, etc.), usually with a reduced water activity (through drying or salt use) [19]; 2) Organoleptic characteristics of the food [20] (Lacroix et al. 2010, Sicard and Legras 2011); 3) Pathogen inhibition hence improving food safety or toxic removal [18] [21]; and 4) Nutritive value improvement [22].

\subsection{Bacteria Strain (Starter Culture) Use}

Starter culture consists of microbiological cultures that function as initiating the fermentation process, in small- and large-scale food production.

Starters are chosen based on the raw material (substrate) being fermented; the starter culture may consist of yeast, a mold of bacteria. Preferred qualities of a starter culture include the provision of sensory characteristics (such as taste, texture, consistency, and aroma), a known fermentation process, fast acidification, and harmful microbiota reduction. A practical culture starter example is carbon dioxide production through fermentation of bread, eyes formation in cheese, and foam formation in buttermilk or beer. It must be a nutrition enhancer, food safety improvement, and provision of quality finished food products [16]. Lactic acid bacteria (LAB) are of high importance in food fermentation.

\subsection{Microbial Activities of Lactic Acid Bacteria (LAB) and Yeast in Food Fermentation}

The frequent microorganisms employed in food fermentations are "Yeast", 
"Bacteria" and "molds". The essential "Bacteria" in food fermentations are

"Lactobacillaceae" which is efficient in producing lactic acid bacteria (LAB) from carbohydrates. Other bacteria are acetobacter, acetic acid-producing bacteria (for fruits and vegetation fermentation), and Bacillus (legumes fermentation) species.

Lactic acid bacterium (LAB) is one of the primary agents used in food fermentation [23]. Their high significance level relates to its physiological features as in metabolic capabilities, substrate utilization, and probiotic properties. Lactic acid bacteria (LAB) like Lactobacillus spp., Streptococcus, and Bifidobacterium spp. are often used in food fermentation. The fermentation with acetic acid has been used widely to manufacture fruit vinegar, including cider vinegar [24].

Lactic acid fermentation is practiced worldwide. It occurs spontaneously in fermented products from the presence of sugar in fruit samples. However, Lactic acid bacteria form part of gram-positive, non-spore forming, cocci, or rod that produces lactic acid as a primary product. Their main means of food preservation is the production of acid, primarily by LAB, that decreases the $\mathrm{pH}$ to a level at which most of the spoilage-causing microbes cannot multiply, and the food is preserved [24] [25]. Again, Lactic Acid Bacteria (LAB) tolerance of high salt concentrations, gives them an advantage over other less salt-tolerant genera, this allows LAB to produce acid that impedes the growth of unwanted microorganisms.

\subsection{Alcohol (Ethanol) Fermentation and Yeast Fermentation}

Alcohol food fermentation is an aerobic method of yeast conversion of pure sugar (glucose, fructose, and sucrose) into cellular energy and producing metabolic end products of ethanol and carbon dioxide [16].

Yeast that has a desirable effect in food fermentation is from Saccharomyces family, mostly $S$. cerevisiae, which is also known as "baker's yeast". The genera are used due to its capability to produce a pleasant flavor and a large quantity of carbon dioxide and a stable shelf-life during storage. Yeasts such as fungi are in the environment. In the food industry, yeast performs a substantial role because they generate enzymes that produce appropriate biochemical reactions such as in the production of beer, ethanol, and leavening of bread [20]. S. Boulderi and Saccharomyces are the most frequent yeast used in the preparation of traditional fermented beverages, mostly those made from maize and millet.

In modern times, large scale production of fermented foods and beverages largely depend on the use of strain starters (starter culture), which have substituted the undefined strain mixtures that were traditionally used for the manufacture of these food products [16].

\section{Overview of Indigenous and Continental Foods Commonly Fermented}

Food fermentation is an ancient practice passed down from many generations to generations, with little to no knowledge of the substantial roles played by yeast 
and lactic acid bacteria (LAB) in the fermentation processes, as well as the beneficial effect of fermented foods in the human gut microbiome. Current trends in food production, preservation, and scientific studies have changed the perspectives of fermented foods. This section discusses food components that are fermented and its origination.

\subsection{Vegetables}

Vegetables refer to the fresh consumable parts of some herbaceous plants, such as roots, stems, leaves, fruits, and flowers; examples include beets, carrots, asparagus, cabbage, cucumber, broccoli, etc. Fermentation of vegetables started around (960 to 1279) in China [26]. Fermentation of vegetables by LAB is possible because of its carbohydrate content such as in pickles, sauerkraut, and olives fermentation [27]. Examples of fermented vegetable food products include Kamal, Dhamuoi, Kimchi, and Tsukemono.

\subsection{Legumes and Cereals}

Cereal is edible grains used in food preparation such as wheat, oat. Yeast (Saccharomyces), fungi genera (Aspergillus, penicillium, etc.), and bacteria (LAB species such as Lactobacillus, Streptococcus, etc.) perform vital roles in the fermentation of cereals and grains, as in leaven bread. Breadmaking dates back in olden times, ancient findings, pottery, and drawings give proof that bread was produced around 10,000 BCE in Egypt. Legumes and cereals food examples include dosa, ogi, idli, kenkey Bhllae, Laao-Zao, iru, kecap, Chinese yeast, Montou, kinema, papadam, Natto, and Hama-natto are useful sources of fermented foods [28].

\subsection{Soybean Fermented Products}

Soya bean is a form of legume, initially cultivated in China (Asia) and Korea. However, fermented soybean product, "tempeh", was invented on the Java island in the 1600s; this was later taken up in Indonesia [29]. Lactic Acid Bacteria (LAB) and yeast Fermented soybean are employed extensively in modern cuisine and natural use, fermentation increases the phenolic and probiotic compounds in grains. Soybean food example includes tempeh, miso, soy sauce.

\subsection{Fermented Milk and Products}

Milk products are a form of food made from milk of mammals, such as goats, cattle sheep, humans, etc. Milk is fermented into yogurt, cheese, and other forms of milk products using a starter culture. In 6000 - 4000, a type of yogurt fermented from milk named "Dahi" was originated in India. More so, Cheesemaking and intake were recorded in 5500 BCE in Kujawy, Poland [30]. Micro-organisms such as LAB that are involved in the fermentation of milk, comprises Lactococcus, Lactobacillus, Streptococcus, Pediococcus, and Leuconostoc. The texture and flavor of cheese, fermented milk is enhanced by the microbial 
starter culture. Fermented food examples include Yogurt, Amasi, Caplis, Datu, Ergo, Kefir, Kisk, Liban, Nono, Noric sour milk, and Trahanas.

\subsection{Fermented Fish Products}

Fish are aquatic animals that are consumed as food and form the primary protein source. Fermented fish products are believed to have originated from South and East Asia, at Mekong basins around 200 BCE to 200 CE. Fish sauces were used as a condiment during the pre-Roman period [31]. Fermented fish food examples include Anchovy, Burong dalag, Kungchao, and Narezushi.

\subsection{Fermented Meats Products}

The cooking and eating of cured, fresh, and fermented meat products were a part of Europe's culture for hundreds of years. Production of sausage-like products distributed from the Roman era throughout southern Europe and nearby areas of the Mediterranean Sea, early meat, and sausage products were possibly fermented [32]. Fermented meat example includes Nem-Chua, fermented pork, and fermented turkey.

\subsection{Fermented Beverages and Beer}

Fermented grains, grapes, and fruits are believed to have started in prehistoric Egypt and Mesopotamia around 4000 BCE. Comparable fermented beverages originated in 2000 BCE in Mexico and Sudan in 1500 BCE [26]. Evidence recovered from in Iran's archaeological places indicates winemaking could have occurred around 6000 BCE. Fermented tea beverages such as kombucha, palm wine are derived from fermented palm sap. Several probiotic beverages are from cereals and grains [33]; they include Bouza, Boza, Bushera, Kaffir beer, Chulli, etc. Table 1 provides examples of different indigenous and continental fermented food products with their probiotic (microorganism) strains.

\section{The Impact of Processing Parameters and Non-Process Factors on Probiotics Potential}

Fermented beverages and manufactured goods are essential because they are a source of a range of probiotics, needed for a healthy microbiome. Currently, research studies are highlighting on health benefits of probiotics. These includes systemic immune-modulatory functions [48], inhibitory of harmful microbial activities in the gut [49], urogenital tract [50], epithelial (skin) [51], modulation of gut-liver axis [52] and the provision of neuroactive metabolites [53]. These studies provide the basis for attracting more usage of probiotics since "antibiotics resistance" have become a threat to human health and the gut microbiome. Figure 1 illustrates how the human gut microbiome is improved through consuming fermented foods with "live microorganisms". The natural form of probiotic is preferable, and more usage of fermented food products with probiotics has been observed [54]. Table 1 presents a list of selected indigenous and continental foods with probiotic strains. Although fermented food products do have 
Table 1. Continental and Indigenous Fermented food products and their associated Probiotics (microorganism).

\begin{tabular}{|c|c|c|c|c|}
\hline $\begin{array}{l}\text { Fermented Food } \\
\text { Product (Name) }\end{array}$ & $\begin{array}{c}\text { Microorganism } \\
\text { (Probiotics strains) }\end{array}$ & Country & Common Ingredient. (Substrate) & References \\
\hline \multicolumn{5}{|c|}{ Fermented milk food products } \\
\hline Amasi/Zifa & Lactococcus. Lactis subsp Lactis & Zimbabwe & Milk & {$[34]$} \\
\hline Caplis & $\begin{array}{l}\text { Lactobacillus } \\
\text { Saccharomyces }\end{array}$ & Japan & Cow milk & {$[35]$} \\
\hline Dahi & $\begin{array}{c}\text { Lactococcus Lactis subsp. } \\
\text { Lactobacillus }\end{array}$ & India & Cow/Buffalo milk. & {$[36]$} \\
\hline Ergo/irgo & Lactobacillus sp. & Ethiopia & Cow milk & {$[37]$} \\
\hline Kefir & $\begin{array}{l}\text { Lactobacillus sp. } \\
\text { Yeast }\end{array}$ & Russia & Cow/goat/sheep milk & {$[38]$} \\
\hline Kisk & Lactobacillus. Casei, Yeast & Egypt, Lebanon, Syria & Milk and wheat & [39] \\
\hline Liban & Lactococcus. Lactis subsp. & Iraq & Cow milk & {$[40]$} \\
\hline Nono & $\begin{array}{l}\text { Lactobacillus acidophilus, } \\
\text { Lactococcus. Lactis subsp. }\end{array}$ & West Africa & Cow/sheep milk & {$[41]$} \\
\hline Nordic sour milk & Lactic acid bacteria. Lactis & Norway, Sweden & Cow milk & {$[35]$} \\
\hline Trahanas & Lactic acid bacteria & Greece Turkey & Wheat, Sheep milk. & {$[40]$} \\
\hline \multicolumn{5}{|c|}{ Fermented legume and cereals food products } \\
\hline Bhallae & Lactic acid bacteria & India & Black gram & {$[41]$} \\
\hline Lao-Zao & Saccharomycopsis & China, Indonesia & Rice & {$[42]$} \\
\hline Hama-natto & Streptococcus sp., Pediococcus & Japan & Soybeans & {$[38]$} \\
\hline Iru & Bacillus sp. & West Africa & Locust bean & {$[43]$} \\
\hline Kecap & Aeromonas & Indonesia & soybeans & {$[44]$} \\
\hline Chinese Yeast & Yeast & China & Maize & {$[44]$} \\
\hline Mantou & Saccharomyces & China & Wheat gluten & {$[45]$} \\
\hline Kinema & Bacillus subtilus & Nepal, India & Soybeans & [46] [47] \\
\hline Papadam/Puda & $\begin{array}{c}\text { Lactic acid bacteria }(L A B) . \\
\text { Yeast. }\end{array}$ & India & Black gram & {$[47]$} \\
\hline Natto & Bacillus & Japan & Soybean & {$[44]$} \\
\hline \multicolumn{5}{|c|}{ Fermented vegetable products } \\
\hline Kawal & Lactobacillus. Plantarum & North Africa & vegetables & {$[38]$} \\
\hline Sauekraut & Lactobacillus. Brevis & Germany & Cabbage & {$[43]$} \\
\hline Dhamuoi & Lactobacillus & Vietnam & Varieties of Cabbage & [44] \\
\hline Kimchi & Lactobacillus. Brevis, & Korea & Korean radish, cabbage, vegetables & {$[45]$} \\
\hline Tsukemono & Lactic acid bacteria $(L A B)$ & Japan & Vegetables, rice flour & {$[46]$} \\
\hline \multicolumn{5}{|c|}{ Fermented fish and meat products } \\
\hline Anchovy & $\begin{array}{c}\text { Lactic acid bacteria }(L A B) . \\
\text { Yeast }\end{array}$ & $\begin{array}{c}\text { Argentina Mediterranean } \\
\text { countries }\end{array}$ & Anchovy & {$[46]$} \\
\hline Burong dalag & $\begin{array}{c}\text { Lactobacillus. Plantarum, } \\
\text { S. faecalis }\end{array}$ & Philipines & $\begin{array}{l}\text { Fish } \\
\text { Rice }\end{array}$ & {$[35]$} \\
\hline
\end{tabular}




\section{Continued}

\begin{tabular}{|c|c|c|c|c|}
\hline Kungchao & P. cerevisiae & Thailand & Rice, Shrimp. & {$[38]$} \\
\hline Narezushi & Lactobacillus. plantarum & Japan & Fish Millet & {$[44]$} \\
\hline Nem-Chua & Lactobacillus sp. & Vietnam & Pork, rice & {$[44]$} \\
\hline \multicolumn{5}{|c|}{ Beverages of fermented foods } \\
\hline Bouza & Lactic acid bacteria $(L A B)$ & Egypt & Wheat, malt & {$[26]$} \\
\hline Boza & $L A B$, Yeast & $\begin{array}{c}\text { Bulgaria, Romania, Turkey, } \\
\text { Albania }\end{array}$ & Wheat, rye, millet, maize & {$[26]$} \\
\hline Bushera & Yeast, $L A B$ & Uganda & Sorghum, millet & {$[26]$} \\
\hline Champus & Yeast & Colombia & Maize & {$[26]$} \\
\hline Cider & Yeast & France, Spain, Ireland & Apple & {$[26]$} \\
\hline Chulli & Yeast & India & Apricot & {$[26]$} \\
\hline Darassum & $L A B$, Yeast & Mongolia & Millet & {$[26]$} \\
\hline Duizou & Yeast, $L A B$ & India & Red Rice & {$[26]$} \\
\hline Gowe (Sifanu) & Yeast, $L A B$ & Benin & Sorghum & {$[26]$} \\
\hline Jou & Yeast, $L A B$ & India & Rice & {$[26]$} \\
\hline Kachasu & $L A B$, Yeast & Zimbabwe & Wild fruits (Ziziphus mauritiana) & {$[26]$} \\
\hline Kaffir Beer & $L A B$, Yeast & South Africa & Sorghum, millet & {$[26]$} \\
\hline Madhu & Yeast, mold & India & Rice & {$[26]$} \\
\hline Mangisi & Yeast, $L A B$ & Zimbabwe & Maize & {$[26]$} \\
\hline Mbege & Yeast, $L A B$ & Tanzania & Malted millet & {$[26]$} \\
\hline Merrisa & Yeast, $L A B$ & Sudan & Millet, cassava & {$[26]$} \\
\hline Nareli & Yeast, $L A B$ & India & Coconut palm & {$[26]$} \\
\hline Palm wine & Yeast, $L A B$ & Palm-growing regions & Palm sap & {$[26]$} \\
\hline Ruhi & Yeast & India & Rice & {$[26]$} \\
\hline Tequila & Yeast & Benin & Agave juice & {$[26]$} \\
\hline
\end{tabular}

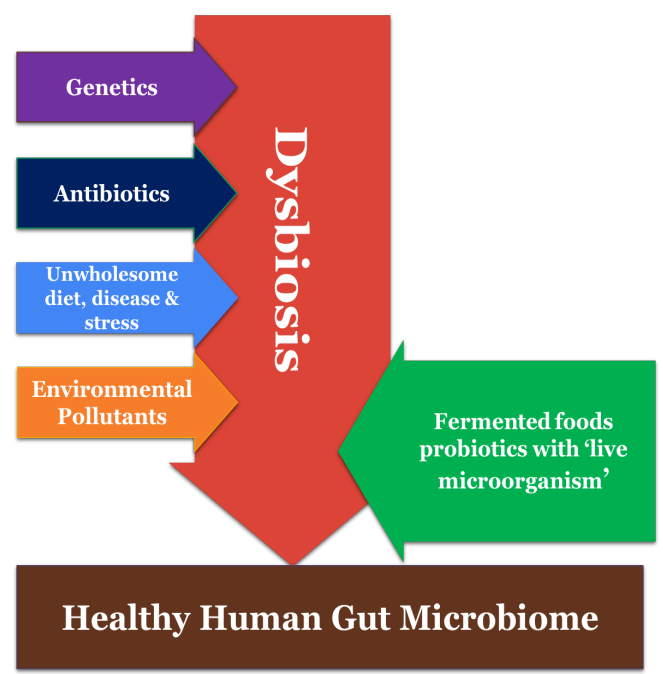

Figure 1. Human gut microbiome restoration with fermented food probiotics. 
naturally occurring probiotics, some studies suggest that the probiotic quality (and potential loss of probiotic capacity) is dependent on how the food is processed. When fermented food products meet exceptional nutritional needs but have no probiotics properties, they are known as functional (nutraceutical) foods [55]. Similarly, when nutritious fermented foods have unidentified microbiological strains or content, they are not considered probiotics. In the subsequent session, the impact of process and non-process factors on the stability and availability of probiotics from fermented food is discussed.

Gupta and Bajaj [56], in their study, isolated Lactobacillus Plantarum M-13 from "Kalarei", an indigenous cheese-like fermented milk with cultures of lactic acid bacteria (LAB). The product is considered a suitable probiotic source. The separated L. Plantarum M-13 showed an excellent survival rate under simulated conditions in gastrointestinal tract microbiota [56].

Likewise, in their similar study, Gupta and Bajaj [56] researched on a non-diary fermented oat-based product development prospect using a probiotic strain Lactobacillus Plantarum M-13 and honey. The isolate, L. Plantarum M-13, a bacterium, has already been mentioned in several studies for its numerous probiotic functional characteristics. The variable incubation duration had a significant positive impact on the viable cell count of $L$. Plantarum M-13. The study also showed that process parameters, including incubation time and honey, had a maximum effect. Good viability of $L$. Plantarum M-13 was seen in Fermented Probiotic Oat Flour during three weeks of storing at room temperature with refrigeration. The study outcome is evident that non-diary carriers are favorable for the growth and survival of probiotics.

In another study by Bambace, Alvarez [57], the researchers processed fruits as probiotics sources. They used the probiotic strain Lactobacillus rhamnosus CECT 8361 in alginate-based coatings enhanced with inulin and oligofructose. The mixture was applied to fresh blueberries. Probiotic viability, physicochemical, microbiological, and sensory quality parameters of blueberries were observed over 21 days of refrigerated storage. The results showed improvement of probiotics, counting greater than $6.2 \mathrm{CFU} / \mathrm{g}$. The product's taste, quality, and smell were acceptable for 14 days of refrigeration storage [57].

Also, Reale, Di Renzo [58] aimed to make two traditional Italian pasta kinds of cheese, by direct-to-vat inoculum of probiotic adjuncts probiotic "mozzarella" and "scamorza", the critical methods used by dairy manufacturing companies to produce fermented cheeses. Cheese-making, effect adjuncts viability was assessed, and the lists of the surviving probiotics determined by $16 \mathrm{SrDNA}$ sequencing.

Acidification, growth and high temperatures tolerance of five strain commercial probiotic cultures were used ( $L$. casei, L. paracasei, and L. rhamnosus). The researchers following dairy farm procedures, quality probiotic, and primary starter were selected and used for "mozzarella" and "scamorza" production. Initially, "Mozzarella" shelf-life refrigerated temperature could not allow the fi- 
nished product to carry reasonable probiotics dose; however, 30 days of maturation increased the probiotic from 10 - 100 times, proving it is an excellent probiotic food-carrier.

More so, [59], experimented on probiotic-fermented juices; probiotic strains of L. Plantarum, B. Breve, and Streptococcus thermophilus were isolated. Most importantly, $S$. thermophilus has excellent selenium tolerance; the Strains in the product make it a probiotic appropriate beverage.

Also, Jeon, Yang [60], in their study of soybean fermentation, the sample extracts revealed an unfermented soybean extract. B. Subtilis, this has potential as a central part of the starter culture of fermented soybean foods. In other studies, vegetables such as Kimchi and Sauerkraut have been recorded to contain high LAB contents.

Most of the indigenous and continental fermented milk products such as kefir, Nordic sour milk, Amasi, have lactic acid bacteria and are considered a source of fermented food probiotics [61] [62], however, Shiby and Mishra [63], reiterated that cultured dairy products connected with health claims should generally contain viable probiotic bacteria recommended levels up to $10^{7} \mathrm{CFU} / \mathrm{g}$. In some countries a minimum $10^{7} \mathrm{CFU} / \mathrm{g}$ per food serving of viable probiotics is supported. In Canada $10^{9} \mathrm{CFU} / \mathrm{g}$ viable probiotics is the advisable administration per day, same as Italy; [1] [64].

Furthermore, Soares, Martinez [65], in their study: Resistance of Bifidobacterium, Lactobacillus, and Bacillus strains with claimed properties of probiotics from different food types were assessed. The strain counts of acclaimed probiotic foods were established through their processing and shelf-life. The survival percentage from the beginning and end of the product self-life of probiotic food samples was inoculated using a static in vitro system in stimulating the gastric ( $\mathrm{pH}$ 2), enteric II (pH7), and stages of the gastrointestinal tract (GIT). The results showed higher viability of Bacillus strains with claimed probiotic properties over probiotic Lactobacillus and Bifidobacterium strains irrespective of the foods studied. Consequently, the study concluded that, because of the strains high in Bacillus resistance to foods composition, processing/manufacturing steps as well as resistance to simulated gastrointestinal conditions, they contain a feasible strategy for expanding "probiotic food" range choices [65].

\section{Conclusion}

In this paper, the probiotic potential of yeast and lactic acid bacterial (LAB) fermented foods is reviewed. Several indigenous fermented foods and their identified probiotic strains are presented. The discussed have shown that Probiotics of Bifidobacterium and Lactobacillus are the most used probiotic strains in fermented foods regardless of the country. Lactic acid bacteria (LAB) (Lactobacillus spp., Streptococcus, and Bifidobacterium spp.) and Yeast (Saccharomyces) are often used in fermentation. Although most commercial food fermentation employs starter culture, it is essential to ensure that fermented probiotic dairy 
products contain $107 \mathrm{CFU} / \mathrm{g}$ "live micro-organisms" per day's serving to be considered a "potential probiotic" fermented food product. All other fermented probiotic food products must contain "viable microorganisms" (confirmed through in vitro testing) and must perform beneficial health roles in the host organism (in vivo testing). It is evident from the review that processing and shelf-life conditions have an impact on probiotic strains' survival in fermented food products. Bacillus was identified to have high resistance to food composition, processing/manufacturing steps as well as resistance to simulated gastrointestinal conditions.

\section{Acknowledgements}

The authors express their gratitude to the Department of Food Science and Agricultural Chemistry, McGill University.

\section{Conflicts of Interest}

The authors declare no conflicts of interest regarding the publication of this paper.

\section{References}

[1] Hill, C., et al. (2014) The International Scientific Association for Probiotics and Prebiotics Consensus Statement on the Scope and Appropriate Use of the Term Probiotic. Nature Reviews Gastroenterology \& Hepatology, 11, 506-514. https://doi.org/10.1038/nrgastro.2014.66

[2] Martins, A.A., et al. (2018) Probiotic Prato Cheese Consumption Attenuates Development of Renal Calculi in Animal Model of Urolithiasis. Journal of Functional Foods, 49, 378-383. https://doi.org/10.1016/j.jff.2018.08.041

[3] Reid, G., Gadir, A.A. and Dhir, R. (2019) Probiotics: Reiterating What They Are and What They Are Not. Frontiers in Microbiology, 10, 424.

https://doi.org/10.3389/fmicb.2019.00424

[4] Rastall, R.A., et al. (2005) Modulation of the Microbial Ecology of the Human Colon by Probiotics, Prebiotics and Synbiotics to Enhance Human Health: An Overview of Enabling Science and Potential Applications. FEMS Microbiology Ecology, 52, 145-152. https://doi.org/10.1016/j.femsec.2005.01.003

[5] Chuayana, E.L.J., et al. (2003) Antimicrobial Activity of Probiotics from Milk Products. 32 .

[6] Amara, A.A. and Shibl, A. (2015) Role of Probiotics in Health Improvement, Infection Control and Disease Treatment and Management. Saudi Pharmaceutical Journal, 23, 107-114. https://doi.org/10.1016/j.jsps.2013.07.001

[7] FAO/WHO (2006) Probiotics in Food: Health and Nutritional Properties and Guidelines for Evaluation. Report of a Joint FAO/WHO Expert Consultation on Evaluation of Health and Nutritional Properties of Probiotics in Food Including Powder Milk with Live Lactic Acid Bacteria, Cordoba, Argentina, 1-4 October 2001 [and] Report of a Joint FAO/WHO Working Group on Drafting Guidelines for the Evaluation of Probiotics in Food, London, Ontario, Canada, 30 April-1 May 2002. FAO Food and Nutrition Paper 85, Food and Agriculture Organization of the United Nations, World Health Organization, Rome. 
[8] Fredua-Agyeman, M. and Gaisford, S. (2019) Assessing Inhibitory Activity of Probiotic Culture Supernatants against Pseudomonas aeruginosa: A Comparative Methodology between Agar Diffusion, Broth Culture and Microcalorimetry. World Journal of Microbiology and Biotechnology, 35, 49. https://doi.org/10.1007/s11274-019-2621-1

[9] Nagpal, R., Yadav, H. and Marotta, F. (2014) Gut Microbiota: The Next-Gen Frontier in Preventive and Therapeutic Medicine? Frontiers in Medicine, 1, Article 15. https://doi.org/10.3389/fmed.2014.00015

[10] Nagpal, R., et al. (2012) Probiotics, Their Health Benefits and Applications for Developing Healthier Foods: A Review. FEMS Microbiology Letters, 334, 1-15. https://doi.org/10.1111/j.1574-6968.2012.02593.x

[11] Kumar, M., et al. (2012) Anticarcinogenic Effect of Probiotic Fermented Milk and Chlorophyllin on Aflatoxin-B1-Induced Liver Carcinogenesis in Rats. British Journal of Nutrition, 107, 1006-1016. https://doi.org/10.1017/S0007114511003953

[12] Kumar, M., et al. (2010) Cancer-Preventing Attributes of Probiotics: An Update. International Journal of Food Sciences and Nutrition, 61, 473-496. https://doi.org/10.3109/09637480903455971

[13] Kumar, M., et al. (2011) Effect of Probiotic Fermented Milk and Chlorophyllin on Gene Expressions and Genotoxicity during AFB1-Induced Hepatocellular Carcinoma. Gene, 490, 54-59. https://doi.org/10.1016/j.gene.2011.09.003

[14] Salminen, S.J., Gueimonde, M. and Isolauri, E. (2005) Probiotics That Modify Disease Risk. The Journal of Nutrition, 135, 1294-1298. https://doi.org/10.1093/jn/135.5.1294

[15] Smid, E.J. and Hugenholtz, J. (2010) Functional Genomics for Food Fermentation Processes. Annual Review of Food Science and Technology, 1, 497-519. https://doi.org/10.1146/annurev.food.102308.124143

[16] Malo, P. and Urquhart, E. (2016) Fermented Foods: Use of Starter Cultures. In: Encylopedia of Food and Health, Academic Press, Cambridge, 681-685. https://doi.org/10.1016/B978-0-12-384947-2.00282-8

[17] De Vuyst, L., et al. (2016) Yeast Diversity of Sourdoughs and Associated Metabolic Properties and Functionalities. International Journal of Food Microbiology, 239, 26-34. https://doi.org/10.1016/j.ijfoodmicro.2016.07.018

[18] Hu, L., et al. (2018) Selection of Non-Saccharomyces Yeasts for Orange Wine Fermentation Based on Their Enological Traits and Volatile Compounds Formation. Journal of Food Science and Technology, 55, 4001-4012. https://doi.org/10.1007/s13197-018-3325-5

[19] Gaggia, F., et al. (2011) The Role of Protective and Probiotic Cultures in Food and Feed and Their Impact in Food Safety. Trends in Food Science \& Technology, 22, S58-S66. https://doi.org/10.1016/j.tifs.2011.03.003

[20] Sicard, D. and Legras, J.-L. (2011) Bread, Beer and Wine: Yeast Domestication in the Saccharomyces sensu stricto Complex. Comptes Rendus Biologies, 334, 229-236. https://doi.org/10.1016/j.crvi.2010.12.016

[21] Adams, M.R. and Nicolaides, L. (1997) Review of the Sensitivity of Different Foodborne Pathogens to Fermentation. Food Control, 8, 227-239. https://doi.org/10.1016/S0956-7135(97)00016-9

[22] van Boekel, M., et al. (2010) A Review on the Beneficial Aspects of Food Processing. Molecular Nutrition \& Food Research, 54, 1215-1247. https://doi.org/10.1002/mnfr.200900608 
[23] Sengun, I. and Karabiyikli, S. (2011) Importance of Acetic Acid Bacteria in Food Industry. Food Control, 22, 647-656. https://doi.org/10.1016/j.foodcont.2010.11.008

[24] Joshi, V.K. and Somesh, S. (2010) Preparation and Evaluation of Sauces from Lactic Acid Fermented Vegetables. Journal of Food Science and Technology, 47, 214-218. https://doi.org/10.1007/s13197-010-0037-x

[25] Frazier, W.C. and Westhoff, D.C. (1998) Food Microbiology. 7th Edition, Tata McGraw Hill, New Delhi.

[26] Tamang, J. and Samuel, D. (2010) Dietary Cultures and Antiquity of Fermented Foods and Beverages. In: Fermented Foods and Beverages of the World, CRC Press, Boca Raton, 1-40. https://doi.org/10.1201/EBK1420094954-c1

[27] Medina, E., et al. (2016) Safety of Fermented Fruits and Vegetables. In: Regulating Safety of Traditional and Ethnic Foods, Academic Press, Cambridge, 355-367. https://doi.org/10.1016/B978-0-12-800605-4.00018-9

[28] Sharma, H.K. and Panesar, P.S. (2018) Technologies in Food Processing. Apple Academic Press, New York. https://doi.org/10.1201/b22422

[29] Shurtleff, W. and Aoyagi, A. (2019) History of Soybeans and Soyfoods in Canada (1831-2019). Soyinfo Center, Lafayette.

[30] Salque, M., et al. (2013) Earliest Evidence for Cheese Making in the Sixth Millennium BC in Northern Europe. Nature, 493, 522-525.

https://doi.org/10.1038/nature11698

[31] Tamang, J.P., et al. (2020) Fermented Foods in a Global Age: East Meets West. Comprehensive Reviews in Food Science and Food Safety, 19, 184-217. https://doi.org/10.1111/1541-4337.12520

[32] Hutkins, R.W. (2018) Microbiology and Technology of Fermented Foods. 2nd Edition, Wiley-Blackwell, New York.

[33] Salmeron, I., Thomas, K. and Pandiella, S. (2015) Effect of Potentially Probiotic Lactic Acid Bacteria on the Physicochemical Composition and Acceptance of Fermented Cereal Beverages. Journal of Functional Foods, 15, 106-115.

https://doi.org/10.1016/j.jff.2015.03.012

[34] Swami, O. and Shah, N. (2017) Role of Probiotics in Diabetes: A Review of Their Rationale and Efficacy. EMJ Diabetes, 5, 104.

[35] Steinkraus, K.H. (1997) Classification of Fermented Foods: Worldwide Review of Household Fermentation Techniques. Food Control, 8, 311-317.

https://doi.org/10.1016/S0956-7135(97)00050-9

[36] Caplice, E. and Fitzgerald, G.F. (1999) Food Fermentations: Role of Microorganisms in Food Production and Preservation. International Journal of Food Microbiology, 50, 131-149. https://doi.org/10.1016/S0168-1605(99)00082-3

[37] Baroudi, A.A.G. and Collins, E.B. (1976) Microorganisms and Characteristics of Laban. Journal of Dairy Science, 59, 200-202. https://doi.org/10.3168/jds.S0022-0302(76)84184-7

[38] Oyewole, O.B. (1997) Lactic Fermented Foods in Africa and Their Benefits. Food Control, 8, 289-297. https://doi.org/10.1016/S0956-7135(97)00075-3

[39] Tamime, A.Y. and Marshall, V.M.E. (1997) Microbiology and Technology of Fermented Milks. In: Law, B.A., Ed., Microbiology and Biochemistry of Cheese and Fermented Milk, Springer US, Boston, 57-152. https://doi.org/10.1007/978-1-4613-1121-8 3

[40] Prajapati, J. and Nair, B. (2008) The History of Fermented Foods. In: Farnworth, E.R., Ed., Fermented Functional Foods, CRC Press, Boca Raton, 1-24. 
[41] Blandino, A., et al. (2003) Cereal-Based Fermented Foods and Beverages. Food Research International, 36, 527-543. https://doi.org/10.1016/S0963-9969(03)00009-7

[42] Kiuchi, K., Natto, H.T. and Äî, A. (2003) Food Made by Fermenting Cooked Soybeans with Bacillus Subtilis (Natto). In: Farnworth, E.R. Ed., Handbook of Fermented Functional Foods, CRC Press, Boca Raton, 227-250.

https://doi.org/10.1201/9780203009727.ch9

[43] Holzapfel, W.H., et al. (1998) Overview of Gut Flora and Probiotics. International Journal of Food Microbiology, 41, 85-101. https://doi.org/10.1016/S0168-1605(98)00044-0

[44] Lee, C.-H. (1997) Lactic Acid Fermented Foods and Their Benefits in Asia. Food Control, 8, 259-269. https://doi.org/10.1016/S0956-7135(97)00015-7

[45] Kwon, H. (2003) Korean Fermented Foods. In: Farnworth, E.R. Ed., Handbook of Fermented Functional Foods, CRC Press, Boca Raton, 287-304. https://doi.org/10.1201/9780203009727.ch12

[46] Aubert, C. (1985) Les aliments fermentes traditionnels: Une richesse meconnue. Collection Les Vrais Aliments d' Aujourd'hui et de Demain. Terre Vivante, Paris.

[47] Orillo, C.A. and Pederson, C.S. (1968) Lactic Acid Bacterial Fermentation of Burong Dalag. Applied Microbiology, 16, 1669-1671. https://doi.org/10.1128/AEM.16.11.1669-1671.1968

[48] Geva-Zatorsky, N., et al. (2017) Mining the Human Gut Microbiota for Immunomodulatory Organisms. Cell, 168, 928-943.e11.

https://doi.org/10.1016/j.cell.2017.01.022

[49] Kau, A.L., et al. (2011) Human Nutrition, the Gut Microbiome and the Immune System. Nature, 474, 327-336. https://doi.org/10.1038/nature10213

[50] Gottschick, C., et al. (2017) The Urinary Microbiota of Men and Women and Its Changes in Women during Bacterial Vaginosis and Antibiotic Treatment. Microbiome, 5, 99. https://doi.org/10.1186/s40168-017-0305-3

[51] Kober, M.-M. and Bowe, W.P. (2015) The Effect of Probiotics on Immune Regulation, Acne, and Photoaging. International Journal of Women's Dermatology, 1, 85-89. https://doi.org/10.1016/j.ijwd.2015.02.001

[52] Bajaj, J.S. (2019) Alcohol, Liver Disease and the Gut Microbiota. Nature Reviews Gastroenterology \& Hepatology, 16, 235-246. https://doi.org/10.1038/s41575-018-0099-1

[53] Valles-Colomer, M., et al. (2019) The Neuroactive Potential of the Human Gut Microbiota in Quality of Life and Depression. Nature Microbiology, 4, 623-632. https://doi.org/10.1038/s41564-018-0337-x

[54] Gibson, G.R., et al. (2017) Expert Consensus Document: The International Scientific Association for Probiotics and Prebiotics (ISAPP) Consensus Statement on the Definition and Scope of Prebiotics. Nature Reviews Gastroenterology \& Hepatology, 14, 491-502. https://doi.org/10.1038/nrgastro.2017.75

[55] Rezac, S., et al. (2018) Fermented Foods as a Dietary Source of Live Organisms. Frontiers in Microbiology, 9, Article No. 1785. https://doi.org/10.3389/fmicb.2018.01785

[56] Gupta, M. and Bajaj, B. (2017) Development of Fermented Oat Flour Beverage as a Potential Probiotic Vehicle. Food Bioscience, 20, 104-109. https://doi.org/10.1016/j.fbio.2017.08.007

[57] Bambace, M.F., Alvarez, M.V. and Moreira, M.d.R. (2019) Novel Functional Blueberries: Fructo-Oligosaccharides and Probiotic Lactobacilli Incorporated into Al- 
ginate Edible Coatings. Food Research International, 122, 653-660. https://doi.org/10.1016/j.foodres.2019.01.040

[58] Reale, A., Di Renzo, T. and Coppola, R. (2019) Factors Affecting Viability of Selected Probiotics during Cheese-Making of Pasta Filata Dairy Products Obtained by Direct-to-Vat Inoculation System. $L W T$, 116, Article ID: 108476.

https://doi.org/10.1016/j.lwt.2019.108476

[59] Xu, X., et al. (2019) Chemical Analysis and Flavor Properties of Blended Orange, Carrot, Apple and Chinese Jujube Juice Fermented by Selenium-Enriched Probiotics. Food Chemistry, 289, 250-258. https://doi.org/10.1016/j.foodchem.2019.03.068

[60] Jeon, H.-L., et al. (2018) Evaluation of Probiotic Bacillus subtilis P229 Isolated from Cheonggukjang and Its Application in Soybean Fermentation. LWT, 97, 94-99.

https://doi.org/10.1016/j.lwt.2018.06.054

[61] Beltrán-Barrientos, L.M., et al. (2018) Randomized Double-Blind Controlled Clinical Trial of the Blood Pressure-Lowering Effect of Fermented Milk with Lactococcus lactis: A Pilot Study. Journal of Dairy Science, 101, 2819-2825. https://doi.org/10.3168/jds.2017-13189

[62] Marco, M.L., et al. (2017) Health Benefits of Fermented Foods: Microbiota and Beyond. Current Opinion in Biotechnology, 44, 94-102. https://doi.org/10.1016/j.copbio.2016.11.010

[63] Shiby, V.K. and Mishra, H.N. (2013) Fermented Milks and Milk Products as Functional Foods-A Review. Critical Reviews in Food Science and Nutrition, 53, 482-496. https://doi.org/10.1080/10408398.2010.547398

[64] del Olmo, A., Picon, A. and Nuñez, M. (2019) Probiotic Dynamics during the Fermentation of Milk Supplemented with Seaweed Extracts: The Effect of Milk Constituents. $L W T, 107,249-255$. https://doi.org/10.1016/j.lwt.2019.03.006

[65] Soares, M., et al. (2019) The Resistance of Bacillus, Bifidobacterium, and Lactobacillus Strains with Claimed Probiotic Properties in Different Food Matrices Exposed to Simulated Gastrointestinal Tract Conditions. Food Research International, 125, Article ID: 108542. https://doi.org/10.1016/j.foodres.2019.108542 